\title{
A Survey Of Best Practices And Key Learning Objectives For Successful Secondary School STEM Academy Settings
}

Paul Kasza, Kelly Walsh High School, USA

Timothy F. Slater, Ph.D., University of Wyoming, USA

\begin{abstract}
Specialized secondary schools in the United States focusing on Science, Technology, Engineering, and Math (STEM) are becoming commonplace in the United States. Such schools are generally referred to by U.S. teachers as Academies. In a purposeful effort to provide a resource to educators building new STEM Academies, this study provides both a review of scholarly literature and the interview results from five successful STEM Academy educators from across the United States. This research addresses two overarching questions, a) what are the best practices of STEM Academies, and b) what are the key learning objectives of STEM Academies? Subject integration, in-house engineering curriculum design, student cohorts, community involvement, and internships were all revealed as being consistently reflective of best practices used in successful STEM Academies. Key learning objectives consistent across the literature and in interview results were: problem solving/the engineering design process and soft skills, such as student collaboration, communication, presentation skills and time management.
\end{abstract}

Keywords: STEM Education; K-12 Schools; STEM Academy; Education Research; $21^{\text {ST }}$ Century Soft Skills; Curriculum Development

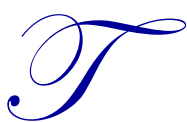

hroughout too much of modern history, western education has mostly consisted of students passively sitting in classrooms, listening to teachers, taking notes, completing assignments, and testing of memorization. Many students do not thrive in this environment as they see it as a long list of unrelated tasks that have no practical meaning to their own lives (Dewey, 1938; Slough, 2013). This traditional approach to teaching has fostered learning for some, yet lacks the authentic approach to education that people have experienced in other cultures for thousands of years, which is on-the-job sharing and collaboration.

Many K-12 educators today are addressing this issue through inquiry, a strategy in which students are shown how to explore their world through a systematic and investigative process. Writers of the United States' curriculum framework Next Generation Science Standards (NGSS) have identified and addressed this need through Engineering content and Science and Engineering Practices (NGSS Lead States, 2013; c.f., Slater \& Slater, 2015). Academies are one approach to fulfilling this hands-on ideology as they are located in high schools where students work in an environment that connects their science, math, and engineering classes, ideally resulting in a real-world experience. These schools offer a realistic hands-on and collaborative environment. Students spend most of their time working together, with their teachers, and community members to solve real-world problems (Marshall, 2010).

Science, Technology, Engineering, and Math (STEM) is a specific subset of education in which academies across the U.S. tend to specialize. One approach of STEM is to use science, math, and technology as tools to actively engineer something, with the engineering processes being the focus of the project (Capraro, 2008). Projects most often begin with students identifying a need in society, which is often an ill-defined task (Capraro, 2008). Students perform research, work with their community, and design a solution. The solution would then be created or manufactured, tested, and compiled into a final product. The scope of the projects can range anywhere from replacing an aging bridge to making a prosthetic finger for an individual. In this context, educators need guidance how to best educate students in STEM. 


\section{BACKGROUND AND CONTEXT}

Over the last decade, there has been a large push for increased STEM education in the United States. Competition in the global market is a strong factor for this, as other nations appear to be advancing more quickly than the US in training students in STEM (Duran, 2013). Conversely, the US seems to have a decreasing interest in STEM (Stearns, 2012), as the Committee on Prospering in the Global Economy states:

Although many people assume that the United States will always be a world leader in science and technology, this may not continue to be the case inasmuch as great minds and ideas exist throughout the world. We fear the abruptness with which a lead in science and technology can be lost - and the difficulty of recovering a lead once lost, if indeed it can be regained at all (2007, p. 3).

Specific reasons for ongoing development development of STEM education in the US are laid out clearly by Marshall,

To educate our children as STEM knowledge creators, innovators, entrepreneurs, and global changemakers with the capacities to understand complex issues, creatively invent solutions, and ethically catalyze change requires their immersion in mind and practice fields rooted in meaning, not memory; engagement, not transmission; inquiry, not compliance; exploration, not acquisition; personalization, not uniformity; interdependence, not independence; collaboration, not competition; challenge, not threat; questions, not answers; and joy, not fear (2010, p. 49).

President Obama stated that if the United States is to maintain its leading role in science and technology, one million more STEM professionals must be trained (President's Council of Advisors on Science and Technology, 2012). Obama goes on to say that, “...we'll reward schools that develop new partnerships with colleges and employers, and create classes that focus on science, technology, engineering, and math - the skills today's employers are looking for to fill the jobs..." (President Obama, White House Office of the Press Secretary, 2013). Finally, the National Science Board reported that between 1950 and 2009 there has only been a 1.2\% increase in Science and Engineering workers while there has been a 5.9\% increase in the need for STEM occupations (2012).

However, some argue that the need for a large expansion in STEM education and careers is being exaggerated unnecessarily. Stevenson states that our current STEM crisis originated during the Cold War with the Soviet Union and its launch of Sputnik. Since then, the recurring cry for more STEM education resides in fear and "a perceived threat to U.S. economic and homeland security" $(2014$, p. 135). Oleson claims that STEM occupations are often poorly classified. He takes this further by stating that these classifications are used in studies that analyze and project present and future needs as well as salaries, many of which are inaccurate (2014). His argument does not negate the need for STEM education but instead requires educators to be able to discern better and effectively teach the skills and knowledge that industry is requiring in our advancing society (Carnevale, 2010).

One solution to improving STEM education is to create specialized K-12 schools, called Academies, which focus on and strongly emphasize STEM across the school's curriculum. Recently, Thomas (2010) described how American academies began as specialized Science, Math, and Technology (SMT) schools. The first, Stuyvesant High School, was opened in 1904 and was a manual training school for boys. Brooklyn Technical High School followed in 1922, then the Bronx High School of Science in 1938. The need for such schools arose to provide opportunities for the working force to develop certain required skills and not for the gifted and talented to excel. The Cold War against the Soviet Union spurred on much of the development of SMT schools in the United States from the 1950's through the 1980's. These new schools began to add the "E", or engineering, component into STEM, and most in the U.S. were state run, not district run.. Now including gifted and talented students, many were (and still are) located on college campuses and offered college credit. Part of the reason for state-run academies, instead of district-run ones, was (and still is) that the facilities, specialized equipment, curriculum development, etc. are expensive, and states and the federal government are often better suited to handle these costs than districts are (Atkinson, 2007). The purpose of these schools was two-fold - to provide a rigorous program for advanced students and to facilitate research into the best approaches to teaching STEM, which can then be modeled to other schools. Thomas sums up the development of academies by stating that the need for these schools, " $\ldots$ has been driven by economics, politics, 
and international affairs, the last two decades have seen a shift in practice that asserts that specialized STEM education is beneficial to both teaching and learning" (2010).

Similar to the definition of STEM, the definition of academy is vague. Erdogan (2015) describes STEM Academies as often being Career Technical Education (CTE) schools where students typically spend half of their day focusing on STEM and the other half at their home school. Schachter defines emerging STEM Academies that have CTE components as, "Formerly called vocational-technical schools, these institutions have long been known for turning out auto mechanics, carpenters and cosmetologists, as well as graduates in dozens of other trades" (2012). Students often take a variety of hands-on CTE classes in addition to Math, Science, Language Arts, and/or engineering design classes. These classes may not be separated by a bell schedule, but instead might have common projects that span all the classes and promote cross-curricular integration (Marshall, 2010). In addition to providing students with hands-on and real-world experiences, these schools prepare them for college and/or try to prevent them from dropping out (Erdogan, 2015).

There is ample evidence that the academy setting can be an effective way to learn STEM. The CSI Academy (Kaye, 2011), Toledo Technology Academy (Dubin, 2014), "Orion Academy” (Morrison, 2015), AL@ (Hougham, 2015), and the Green Energy Academy (Schachter, 2012), just to name a few, all showed how students outperformed their counterparts in traditional schools and/or were better prepared for STEM related occupations than peers. The National Academy of Sciences has strongly recommended that specialty high schools be developed to enhance science and math, as these schools can,

...foster leaders in science, technology, and mathematics. Specialty schools immerse students in highquality science, technology, and mathematics education; serve as a mechanism to test teaching materials; provide a training ground for $K-12$ teachers; and provide the resources and staff for summer programs that introduce students to science and mathematics (Committee on Prospering in the Global Economy of the 21st Century, 2007).

Erdogan (2015) compiled statistics involving STEM Academies. He found that $9^{\text {th }}$ graders in such academies were more interested in STEM subjects and more confident that they would graduate from high school and earn a college degree as compared to their traditional school counterparts. Also, STEM Academy students in Texas scored higher on the math and science portions of the state tests than did traditional students. Erdogan describes 1,032 students after graduation from STEM Academies and found:

Seventy-five percent indicated a desire to continue education beyond high school and $40 \%$ planned to obtain a doctorate. Fifty-one percent of students who graduated from specialized STEM schools pursued a science major in college. Results from this study suggested $10 \%$ of students who graduated from specialized STEM schools went on to major in mathematics. In addition, results of this study indicated $60 \%$ of college freshman participants expected to earn a STEM degree and 55\% of college senior participants were about to earn a STEM degree (p. 85).

One potential issue with academies is student scores on standardized tests are frequently used to assess student achievement for a variety of reasons. These tests can potentially impact school autonomy, funding, extracurricular activities, electives, etc. Dixon describes how there is a lack of solid evidence showing that students who study in academies do better than their non-academy peers on science and math portions of the standardized tests. He goes on to say that if technology and engineering educators can reach a better point of collaboration with math and science teachers, standardized test scores will go up (2012). Roberts describes how most critics of STEM Academies do not dismiss their benefits, but instead say that the drawbacks outweigh the benefits, chiefly the difficulty in generating a functionally integrated curriculum (2013). In other words, do students become more STEM-literate in an academy setting as compared to a traditional school setting, as academies are more time and money demanding? 


\section{BEST PRACTICES OF STEM ACADEMIES FROM THE LITERATURE}

STEM Academies are unique environments that require special approaches to make them effective. A review of the literate has returned the following best practices: having students in the integration of various subjects, cohorts, and community involvement. Each of these will be discussed in further detail.

Subject Integration in STEM Academies is inherent in the definition of STEM itself, as the National Governors Association states:

STEM literacy is an interdisciplinary area of study that bridges the four areas of science, technology, engineering, and mathematics. STEM literacy does not simply mean achieving literacy in these four strands or silos. Consequently, a STEM classroom shifts students away from learning discrete bits and pieces of phenomenon and rote procedures and toward investigating and questioning the interrelated facets of the world (2007, p. 7).

This is in contrast to what Hoachlander says about the current status of STEM in most schools, as it consists of science and math, with technology and engineering being left out or an afterthought (2011). Hoachlander continues, "Where connections do get made to technology and engineering, too often they happen through a hodgepodge of disconnected projects that lack coherence or strong grounding in content standards and student performance objectives" (2011). The need for such integration arises from the type of problems that society is presented with which often requires a multidisciplinary approach (Roehrig, 2012). Both Hoachlander and Roehrig go on to say that although educators understand the necessity for STEM integration, no common approach exists for carrying it out. One idea is to offer an engineering course and have its projects be the main focus of STEM (Asunda, 2016; Berland, 2013; Roehring, 2012). This approach potentially allows the integration of the STEM subjects, as, "...in the real world, engineering is not performed in isolation-it inevitably involves science, technology, and mathematics" (Katehi, 2009, p. 165).

Cohorts, sometimes called learning communities, are defined by Doolen as, “...an intentional linkage or cluster of two or more courses, often around an interdisciplinary theme or problem, which enrolls a common cohort of students", which usually consists of 20 to 30 students who share the same core class schedule (2014). These courses can consist of writing, mathematics, science, and engineering courses, with the engineering course serving as the primary focus course. Doolen goes on to discuss that cohorts can potentially help students develop strong relationships with each other which can substantially enhance academic success (2014). Ricks performed a study with engineering students at a university to attempt to address three main areas that the students struggled with finances, math literacy, and a sense of belonging. The results of the study took the notion of cohorts to a high level, with:

Scholarships were made available to address the financial issues; tutors, mentors, study groups, and a "freshman-to-sophomore bridge" summer program were provided to address math deficiencies; cohort engineering courses, active learning techniques involving field trips and hands-on projects, required group meetings, required study sessions, peer mentoring, dedicated study space and dedicated faculty advisors were used to promote a sense of community and belonging as well as improved study habits (2014, p. 88).

The study also showed students in such a rigorous cohort had a high retention and graduation rate.

Community Involvement is another area that the literature indicates that significantly impacts learning in STEM Academies. Examples of community members include businesses, government agencies (Southern Regional Education Board, 2012), research lab scientists and engineers, university faculty, (Morrison, 2015), museums, professional organizations (Diaz-Rubio, 2013), clubs, and local activists and educators (Peters Burton, 2014). DiazRubio describes how local businesses provide opportunities for students to engage in real-world problems, as they:

- Offer career presentations that allow students to consider career opportunities.

- Support employees to become mentors to students and teachers in particular fields...

- Facilitate field trips to their sites for hands-on understanding of the organization. 
- Work directly with teachers in the classroom to make lessons more practical for students.

- Offer high school students externships and the opportunity to augment classroom study with real-world work experience, as well as internships that offer applied training. Most business people want to get involved with school partnerships because students are their future workforce (2013).

One example of community involvement was the North and South Glenbrook High Schools being invited by Allstate Insurance Company to attempt to better understand the severity of teen texting while driving and how to reduce this problem. Students clarified these research questions, determined how to collect data, analyzed the data, performed additional research, compiled their results in both written and oral form, then presented their projects to Allstate Insurance representatives (Southern Regional Education Board, 2012).

\section{KEY LEARNING OBJECTIVES OF STEM ACADEMIES}

Our survey of the literature reveals what appears to be three consistent Key Learning Objectives of STEM Academies: problem solving (Engineering Design Process or inquiry), soft skills (professionalism), and collaboration (communication or teamwork). This list is not exhaustive, and crossover occurs regularly between these components.

Problem Solving is at the core of STEM Academies. Morrison defines problem solving as, "...students' collaboration, inquiry, creativity, and critical thinking while engaged in rigorous standards-based curriculum and authentic and meaningful learning involving real-world and open-ended challenges or problems" (2015, p. 245). Problem solving requires high levels of critical thinking in order to work with information that doesn't have a predetermined outcome (Morrison, 2015). Ill-defined problems use such information, and if students are able to personalize these problems, they become much more motivated to engage in higher levels of critical thinking (Pintrich, 1990). When properly trained, students can identify the underlying concepts and approaches to problems, which goes beyond simply making surface connections regarding similar problems (Dixon, 2012). Oleson states, "...employers are clamoring for workers who not only have technical expertise in a particular area such as STEM, but also those who can use their technical knowledge to engage in abstract reasoning, problem-solving, and troubleshooting" (2014), which confirms the post-high school graduate's need for this skill.

Soft Skills is another learning objective that is found in the literature. Much of education is driven towards obtaining the hard skills, such as technical skill and knowledge, but the literature describes how both colleges and industry are looking for individuals with both hard and soft skills (Bancino, 2007; Harris, 2008; Oleson, 2014). Harris has compiled a list of such skills, including, "... work ethics, positive attitude, social grace, facility with language, friendliness, integrity, and the willingness to learn" (2008, p.19). Harris also assembled a panel of engineering professors, and through a Delphi study he found that the most important skill was written communication, with the others being, "...a high level of reading comprehension, demonstration of honesty, a willingness to learn, being open minded to new ideas, problem-solving skills, and the ability to follow directions" (2008, p 22). These were followed up with oral communication and a strong work ethic. Bancino describes in-person, nonverbal, active listening, writing, and presentation communication types along with the idea that there are several underlying skills that contribute to communications skills, including, "...interpersonal skills such as self-awareness, social awareness, relationship management, conflict management and diversity" (2007, p. 21). Harris goes on to share techniques that teachers can use to attempt to develop their students' soft skills, with:

... 1) work in teams, 2) organize their thoughts, 3) communicate with team members, 4) solve a problem, 5) present their findings orally, and 6) evaluate their success through a written document. This type of learning activity should also cause students to work outside of their comfort zone, thereby stretching softskill development. (2008, $\mathrm{p} 22)$.

Collaboration is also an important aspect of STEM Academies. Emphasizing teamwork over individuality, it can be defined as "...a process by which individuals negotiate and share meanings relevant to the problem-solving task at hand... Collaboration is a coordinated, synchronous activity that is the result of a continued attempt to construct and maintain a shared conception of a problem" (Roschelle, 1995, p. 70). Havice (2009) describes how the goal of collaboration is not to have students complete tasks in group situations but is instead to teach them how to work 
together to complete tasks. Students should be instructed in how to effectively work together, fulfill specific roles in the group, work under leadership, avoid allowing the strongest students to take on the majority of the decision making and work load, etc. Deadlines and high expectations enhance group work, which forces students to become efficient and capable. Also, the diversity of students allows a variety of viewpoints and expertise to be used to generate ideas and foster creativity for problem solving (Householder, 2012).

Taken together, the authors described above describe what could be important components of hypothetical STEM academies. However, few of these authors are active educators within STEM academies, which motivates a farther reaching question of, "what do educators actively working inside STEM academies see as the most important components of successful learning environments with a STEM focus?"

\section{METHOD}

\section{Participants}

For the purpose of obtaining answers to the study's overarching questions, we performed five interviews with educators who are involved in STEM Academies, which are located throughout the United States. We found these academies by using internet searches, then by browsing their websites. If an academy seemed to meet the criteria of focusing on Engineering as a part of STEM, we initiated contact by email. Interviews were conducted by the first author, who described the nature of the study and asked participants if they would be interested in visiting confidentially on the phone to aid in our research. Three of the interviews were with coordinators who were also instructors in their academy. Another interview was with someone who is an educator, and the last was with someone who coordinates the program. After the phone interviews, we emailed the contacts with several more clarifying questions; all responded back and answered our questions.

Many of the individuals that were interviewed use curriculum from Project Lead the Way (PLTW), which is a nonprofit organization that offers a variety of pathways for high school, including Engineering, Biomedical Science, and Computer Science. PLTW develops curriculum collaboratively with its own staff, and its customer's students, teachers, and administrators. It is problem-based which is demonstrated through its projects and activities having the goal of providing scaffolding experiences for students to solve problems. In order to be involved with PLTW, schools must pay for teacher training, equipment and supplies, and the participation fee. Once a school is set up, it has a variety of courses from which to choose, which for the Engineering Program includes two foundation courses: Introduction to Engineering Design, Principles of Engineering, and seven advanced courses: Aerospace Engineering, Civil Engineering and Architecture, Computer Integrated Manufacturing, Computer Science Principles, Digital Electronics, Environmental Sustainability, and Capstone Course - Engineering Design and Development. Each of these courses contains modules, which are focused areas of content that take approximately ten hours of class time to administer ("Project Lead the Way", 2013).

Another common organization that was involved with interviewed schools was the National Academy Foundation (NAF). Established in 1982 in New York City, it has grown to facilitate 716 academies and approximately 89,000 students nationwide. Its mission is to, "solve some of the biggest challenges facing education and the economy by bringing education, business, and community leaders together to transform the high school experience" (National Academy Foundation, 2016). In order to facilitate this mission, NAF focuses on four main educational design areas: Academy Development \& Structure, Curriculum \& Instruction, Advisory Board, and Work-Based Learning. Finally, it facilitates five main themes, including Finance, Hospitality \& Tourism, Information Technology, Engineering, and Health Sciences.

\section{Academy Interviews}

The Engineering Academy at Hoover High School (EAH)

Located in Hoover, Alabama, Hoover High School has approximately 2,900 students. It is a public school and consists of a variety of academies and specialty programs, one of which is EAH. Approximately 200 students are enrolled in EAH. This four-year program involves students taking math, science, and engineering courses with a 
mission of, "...exciting students about the engineering profession and preparing them to be successful in engineering at the undergraduate level." (Hoover High School, 2016). Eighth-graders go through an application process to get into the academy which helps them better understand the courses, level of commitment, etc. This application process aids in setting high expectations and a productivity-orientated atmosphere in the program.

My contact at EAH shared what he believes are some of the best practices at his academy. Much of the curriculum at EAH was developed by in-house teachers who have a background in engineering. This provides a flexible yet focused framework that offers students an excellent opportunity to learn. This curriculum connects learning project by project, and year by year. Next, feedback is emphasized over grading. He described how teachers spend a significant amount of time with individual students as they discuss where students are, where they want to be, and how they will get to that point. Students readily buy into this approach. When asked about cohorts, my contact said that the large number of students and the variety of their schedules do not allow for cohorts. Also, due to the diversity of student schedules, integration between courses is minimal, and teachers are not yet at the point where they collaborate cross-content.

Next, he shared some of the main learning goals that the academy has for the students. Problem solving is heavily emphasized, as students step through the engineering design process regularly in their assignments and projects. My contact stated that they, “...encourage students to approach assignments like technical papers and presentations from a design perspective, designing what and how they will communicate given the specifications and constraints for a particular assignment" (2016). Soft skills are another key learning objective. My contact described how university and industry assume that students have acquired these skills, but they are seldom taught and developed. EAH focuses on, "written \& oral communication (formal and informal), working effectively as part of a group, time management, asking questions, and taking responsibility for personal learning" (2016). This also includes public speaking, email, hard copy reports, and technical writing pieces, just to name a few.

Finally, when asked how his academy assesses student success, my contact said that one way is through the documentation of the year-to-year retention of students in the program, which is excellent, and eight graders consistently enroll in their program. They also monitor how well the Academy students do in their math and science courses as compared to other students in the school. EAH's primary measure of success is tracking what students do post-graduation, as the school attempts to stay in contact with students after they move on. Many graduates come back to the school and share their college and work-related experiences on a voluntary basis.

\section{Mallard Creek High School Academy of Engineering (MCAE)}

Mallard Creek High School is a public school in Charlotte, North Carolina, and has approximately 2,200 students. It has a variety of specialty programs, including the Academy of Engineering, in which approximately 200 students are enrolled. Its mission statement is:

...devoted to preparing students in a global society through a quality education. Its goal is to help students prepare for post-secondary education while exposing then to full range of careers in engineering. The focus of the program is to expose and develop skills necessary for success at the next level of education (Mallard Creek High School, 2016).

Students take their core Science, Math, and English courses in conjunction with Project Lead the Way driven engineering classes over the course of 4 years. The program is also heavily involved with NAF.

When asked about their approach to an effective academy, my contact at MCAE discussed the importance of their academic team, which consists of the director, the instruction coordinator, the career development coordinator, and the teachers. They are a cohesive group that complements each other well and work together to form the best academy possible. The MCAE contact also discussed the importance of collaboration and communication amongst the teachers. They have the same lunch and meet unofficially to discuss curriculum, and starting next year they will have specific times set up for weekly meetings. Both subject integration and having students in cohorts are two other important pieces that are still in the development at MCAE. The limited implementation of both of these approaches has yielded positive results, so there are plans to enhance them starting the next academic year. 
Key learning objectives at MCAE include soft skills, as the academy relies heavily on the Mayor's Youth Employment Program to teach this objective. This program, specific to Charlotte, NC, has the goal, "To improve neighborhood quality of life through a community engagement strategy that ensures children are safe, succeeding in school, and supported by their community" (Mayor's Youth Employment Program, 2015). Here students interact with local business members and associated programs in a purposeful manner to learn employability skills, with one such event being an etiquette dinner. Also, problem solving is another essential learning goal. Students use a hands-on collaborative approach when engaging projects which enhances learning and the ability to solve complex problems.

The MCAE contact shared that the end of the course test and standardized tests are used to assess the effectiveness of MCAE. At this time $100 \%$ of the students received internships, graduate, and go to postsecondary schools. The program continues to grow as more students enroll in it each year.

\section{STEM Academy of Hollywood (SAH)}

SAH is a pilot school in Hollywood, California, that offers two different pathways - engineering and medicine ("Medicine" replaces "Math" in STEM). Their mission is to have a strong program to meet high standards, to offer enrichment opportunities to help students grow "cognitively, socially, emotionally, morally and physically," and to provide a "focused and comprehensive series of course in the fields of... STEM" (STEM Academy of Hollywood, 2016). With approximately 600 students, it is a neighborhood school of choice. Students must go through an application process in order to gain admission here on a first come first serve basis. This school uses PLTW for curriculum, yet is a full-service school in which students take their foreign language, social studies, art, etc. classes.

When discussing with my contact some of the best practices at SAH, she emphasized the importance of students being in cohorts. They take most of their classes together, develop relationships, learn how to work well together, and carry over much from class to class and year to year. A competitive atmosphere is also a significant component in the program as students engage in a variety of projects. This elevates student energy, enthusiasm, work ethic, commitment, and standards. Also, she described her use of mini-projects built within larger projects. Students need smaller goals and connecting points in order to obtain individual learning objectives and piece together steps towards an overarching idea. Next, my SAH contact discussed the integration of projects throughout three to five courses. At least once per year, such a project takes place which is driven primarily by the engineering course. Teachers meet at the beginning of the year to plan out these projects, and they create/modify projects in such a way that each year students are exposed to different types of engineering problems. Finally, community involvement is an integral part of SAH. Local engineers help in the creation of projects and serve on judging panels. For example, some engineers have attended classes and helped, planned, and mentored students during a bridge contest. Internships are also a part of the program, but the school struggles in securing positions for students, which is becoming more of a priority for future classes.

One learning objective at $\mathrm{SAH}$ is the use of the engineering design process, which is a common thread throughout most all assignments and projects. The SAH contact described how students ask many questions when presented with a task or problem as they seek out the "right" solution. However, they are often reminded that their constraints help to focus their creativity in approaching solutions, which is an important goal for the students. Soft skills are also a priority at SAH, such as collaboration. Students are generally required to work in groups, and the projects are scaled such that a single student cannot do all the work alone. This forces students to work together and become better team players. Leadership is also emphasized, as the instructor chooses students who have excelled in the content to head up groups. This approach prevents those who are strong academically from becoming bored, and gives them an opportunity to grow in a relevant area of life.

Success at SAH is measured by the instructors, most of whom have degrees in engineering. As discussed previously, practicing engineers also come in and help assess student work, particularly projects. Finally, students who attend SAH have additional requirements that go beyond the state's minimum college requirements, which demonstrates the rigor of the program. SAH is also compared to the other schools in the Los Angeles Unified School District through the ACT, SAT, Smarter Balanced Assessment Consortium assessment, California Standardized Tests, graduation rates, and college acceptance rates. 
Vance Academy of Engineering (VAE)

Zebulon B. Vance High School is located in Charlotte, North Carolina, and is a public school with about 1,700 students. It contains VAE which has approximately 230 students, grades 9-12. Much of the students' courses are pre-determined, such as Math, Science, Social Studies, English, Foreign Language, Engineering, Career and Technical Education, etc., excluding some electives. PLTW is used to direct the engineering curriculum, and the Academy is also associated with NAF. VAE's vision includes exposing and preparing students in STEM fields, to make them competitive post-graduation, and to provide authentic work-based experiences, all of which are reflected in the advanced degree that they receive upon graduation (Vance Academy of Engineering, 2016).

My contact at VAE shared several best practices that they focus on for creating a successful STEM Academy. First, community involvement is essential, as is indicated by the 34 hours of internship that is tailored to each student's program. Various business community leaders serve in quarterly advisory board meetings to brainstorm potential solutions to various problems. They also provide financial support, such as the recent $\$ 20,000$ donation to upgrade classroom technologies. Next, he discussed the importance of cross-subject integration, but he believed the Academy has plenty of room to grow in this area. He also described how advocating for students during registration and making direct connections with parents are important. This allows both students and parents to have an excellent idea as to what VAE consists of, what opportunities exist for the student, and to make personal connections with teachers and administrators.

College and Career Readiness skills drive the learning objectives at VAE. Soft skills, such as collaboration, teamwork, and communication are such objectives. My contact elaborated on this further in that soft skills are just as important as technical skill attainment, and, "this type of learning best happens in a problem-based, project-based learning environment (which is) reflective of what businesses experience" (2016). Students are expected to use the engineering design process and grow in creativity and critical thinking throughout each Career/Technical and PLTW course that they take. My contact emphasized that these courses are designed with a focus on workplace learning in tandem with local businesses in order to, “... best serve students skill development in both areas of soft skills and technical skill attainment" (2016).

VAE's success is assessed in a variety of ways. The student survey is an online survey that asks a variety of multiple choice and essay questions to get feedback on whether or not the program is meeting student needs. The program also has an advanced high school degree, a STEM/Academy of Engineering Diploma, which is available to students who meet VAE's requirements. Post-graduate statistics are collected for post-secondary enrollment, entrylevel employment after high school in professional career fields, and NAFTrack Certifications.

\section{Engineering and Design Academy at Antioch High School (EDAA)}

Antioch High School is a public school located in Antioch, California, and has approximately 2,000 students. It houses a variety of academies and eighth-grade students must choose an academy prior to entering high school, which involves an application and lottery process. Each academy has its own counselor and vice principal, and teachers in the same cohort share a common prep period. The Engineering and Design Academy has a mission of, "Engaging students in engineering, environmental science, and design to prepare them to be innovative leaders ensuring a sustainable society through success in education, career, and life", ("Antioch High School: Engineering and Design Academy," 2016). There are approximately 400 students in EDAA, and it uses the NAF model and PTLW.

When discussing some of the best practices at EDAA, my contact emphasized the community aspect of the academy. Most teachers and students know each other, which enhances accountability both inside and outside of the classroom. Parents are also heavily involved, with those in the Engineering and Design Academy far outnumbering the parents in the other academies within the school. The personalities and complimentary aspects of the teachers are also important, as they work well together. Next, subject integration is prevalent at EDAA. There is at least one major project each semester that is integrated throughout the core and engineering courses. Students often work on these projects in cohorts, as they attend the same classes together, year after year. Projects begin freshman year with simple and broad concepts, then become more focused each year, with the senior project being individualized and of 
a more focused scope. Community involvement is another important aspect of the academy, as local industry brings in real-world projects for the students to work on. My contact stated that,

In all of these activities plus many others, the community and industry partners come in as volunteers to assess, critique, evaluate, offer feedback and suggestions, or judge projects both to offer assistance during the project and to determine the project that best meets the requirements or needs presented. (2016)

There are several learning targets for students at EDAA. My contact stated that soft skills are the single most important skill that they learn in the program. They grow in their presentation skills, oral skills, written skill, choosing appropriate clothing, greeting, punctuality, etc. These skills are emphasized in most, if not all, of their classes. Next, collaboration is important, due to its real-world relevance. Students are often given roles of actual engineering jobs, and they learn how to work well in teams to manage a project. This experience is enhanced through the use of cohorts, as previously discussed. Problem Solving is also heavily emphasized at EDAA. Beginning in their freshmen year, students are taught that this process is just as important as the final product and that they can learn as much from failures as they can from successes. My contact shared the school's abbreviated 5 step Engineering Design Process:

1. Problem: identify and define the problem to be solved.

2. Possibilities: brainstorm and research possible solutions to the problem, then refine the definition of the problem if necessary.

3. Plans: design and develop the plan for how the problem will be solved and the solution will be implemented. If flaws in the plans are found, then return to the prior steps and refine.

4. Prototypes: construct a working model or test case to implement the plans. Again, if flaws are found, return to the prior steps and refine. Use the prototype to conduct tests to ensure the solution works as intended and solves the problem as defined.

5. Products: (finalize and present) the solution with all supporting documentation, models, analysis, budget, and marketing plan.

EDAA measures success in a variety of ways. First, attendance has increased significantly since the inception of the academy. My contact attributes this in part to the community feel of the Academy, as teachers and students hold each other accountable. Next, students are passing standardized tests at higher rates than before EDAA opened, which is emphasized in conjunction with the fact that engineering students are heavily tested in college. Finally, the retention rate of the program has been $100 \%$. Although students sometimes move onto other academies in the school, all have graduated.

\section{DISCUSSION}

The Academy educators that were interviewed shared a variety of over-arching themes in answer to the overarching study questions: a) what are the best practices of STEM Academies, and a) what are the key learning objectives of STEM Academies?

\section{Best Practice Results}

The interviews yielded a variety of best practices, some of which are mentioned by several schools. Table 1 outlines these results, with the most common response being Subject Integration. This was most often accomplished through each Academy's Engineering Class, which would have a large project that drew in the students' other courses (English, Math, Physics, etc.). Most interviewees stated that they would like to step more fully into the development of Subject Integration for their academies.

Next, most schools indicated that they value designing their curriculum in-house (or modifying PLTW curriculum to better suit their needs). The use of Student Cohorts was also a priority, but this was often described as being difficult to implement (due to the variety of student schedules, course offerings, etc.), so they are in the process of attempting to enhance this best practice. Community Involvement was another common component, which was often manifested through local business helping to develop lessons, offer real-world projects and problems, and 
provide grading/feedback, just to name a few. Government agencies, national business, and other organizations also contributed to the schools.

Internships were another common aspect of many of the academies, which were provided for by businesses that practice in relevant areas. having a cohesive teaching team, recruitment and parent involvement, feedback being prioritized over grading, having a competitive atmosphere, using mini-projects to connect bigger projects, and teacher-student relationships were other less often mentioned best practices.

Table 1. Best Practice Results

\begin{tabular}{|c|c|c|c|c|c|c|}
\hline Best Practices & EAH & MCAE & SAH & VAE & EDAA & Count \\
\hline Subject Integration & & $\mathrm{x}$ & $\mathrm{x}$ & $\mathrm{x}$ & $\mathrm{x}$ & 4 \\
\hline In-house Engineering Curriculum Design & $\mathrm{x}$ & $\mathrm{x}$ & $\mathrm{x}$ & & & 3 \\
\hline Student Cohorts & & $\mathrm{x}$ & $\mathrm{x}$ & & $\mathrm{x}$ & 3 \\
\hline Community Involvement & & & $\mathrm{x}$ & $\mathrm{x}$ & $\mathrm{x}$ & 3 \\
\hline Internships & & $\mathrm{x}$ & $\mathrm{x}$ & $\mathrm{x}$ & & 3 \\
\hline Cohesive Teaching Team & & $\mathrm{x}$ & & & $\mathrm{x}$ & 2 \\
\hline Recruitment and Parent Involvement & & & & $\mathrm{x}$ & $\mathrm{x}$ & 2 \\
\hline Feedback Over Grading & $\mathrm{x}$ & & & & & 1 \\
\hline Competitive Atmosphere & & & $\mathrm{x}$ & & & 1 \\
\hline Mini-Projects to Connect Bigger Projects & & & $\mathrm{x}$ & & & 1 \\
\hline Teacher-Student Relationships & & & & & $\mathrm{x}$ & 1 \\
\hline
\end{tabular}

\section{Key Learning Objective Results}

A variety of Learning Objectives were inferred from reviewing interviewers' notes. All five schools described Problem Solving (also referred to as the Engineering Design Procedure) as being an essential component of their program. Soft Skills was also discussed as being essential by all five schools, with some indicating that it is the most important. This importance was emphasized, as the remainder of the learning objectives were all subsets of soft skills. From most to least often mentioned, student collaboration, written communication, oral communication, presentation, time management, appearance, social engagement, asking questions, taking responsibility for personal learning, and leadership were various soft skills that were discussed, as outlined below in Table 2.

Table 2. Key Learning Objective Results

\begin{tabular}{|c|c|c|c|c|c|c|}
\hline Key Learning Objectives & EAH & MCAE & SAH & VAE & EDAA & Count \\
\hline Problem Solving/Engineering Design Process & $\mathrm{x}$ & $\mathrm{x}$ & $\mathrm{x}$ & $\mathrm{x}$ & $\mathrm{x}$ & 5 \\
\hline Soft Skills & $\mathrm{x}$ & $\mathrm{x}$ & $\mathrm{x}$ & $\mathrm{x}$ & $\mathrm{x}$ & 5 \\
\hline Student Collaboration & $\mathrm{x}$ & $\mathrm{x}$ & $\mathrm{x}$ & $\mathrm{x}$ & $\mathrm{x}$ & 5 \\
\hline Written Communication & $\mathrm{x}$ & & $\mathrm{x}$ & & $\mathrm{x}$ & 3 \\
\hline Oral Communication & $\mathrm{x}$ & & $\mathrm{x}$ & & $\mathrm{x}$ & 3 \\
\hline Presentation & $\mathrm{x}$ & & & & $\mathrm{x}$ & 2 \\
\hline Time Management & $\mathrm{x}$ & & & & $\mathrm{x}$ & 2 \\
\hline Appearance & & & & & $\mathrm{x}$ & 1 \\
\hline Social Engagement & & & & & $\mathrm{x}$ & 1 \\
\hline Asking Questions & $\mathrm{x}$ & & & & & 1 \\
\hline Taking Responsibility for Personal Learning & $\mathrm{x}$ & & & & & 1 \\
\hline Leadership & & & $\mathrm{x}$ & & & 1 \\
\hline
\end{tabular}

\section{CONCLUSIONS}

The results of this two-phase study of the literature and of active Academy educators provide our community with a list of recommendations based on the literature's and interviewees' perspectives on the best practices and key learning objectives for STEM Academies. Academies at the secondary level are an exciting approach to STEM 
education. They facilitate hands-on, real-world experiences that not only allow for deeper, more meaningful learning but also provide students with the opportunity to both better identify and begin their journey down a career path. The best practices and key learning objectives of STEM Academies revealed by the literature and through interviews, help to verify the above statements, as they also line up with Dewey's Experiential Learning Theory. Based on the data acquired here, we believe this approach has the opportunity to be clearly superior to the traditional model of learning in which students sit through lectures (often involving copious amounts of theory) and engage in labs that may or may not have relevant connection to the lectured material.

\section{ACKNOWLEDGEMENT}

This work is derived in large part from the first author's unpublished Masters Thesis project which is posted online at http://repository.uwyo.edu/smtc_plan_b/44/

\section{AUTHOR BIOGRAPHIES}

Mr. Paul Kasza teaches Physics and Physical Science at Kelly Walsh High School, in Casper, Wyoming and has worked on developing plans for the Pathways Innovation Center, a proposed STEM Academy school in Wyoming. Email: PaulKasza@hotmail.com (corresponding author)

Dr. Timothy F. Slater is the University of Wyoming Excellence in Higher Education Endowed Chair of Science Education, a Professor in the UW College of Education, and a Senior Fellow at the CAPER Center for Astronomy \& Physics Education Research. His research focuses on understanding teaching and learning in science courses. Email:TimSlaterWyo@gmail.com

\section{REFERENCES}

Antioch High School: Engineering and Design Academy. (2016). Engineering and Design Academy. Retrieved March 29, 2016, from http://ahs-antioch-ca.schoolloop.com/Engineering

Asunda, P. A., \& Mativo, J. (2016). Integrated STEM: A New Primer for Teaching Technology Education. Technology and Engineering Teacher, 75(4), 8-13.

Atkinson, R. D., Hugo, J., Lundgren, D., Shapiro, M. J., \& Thomas, J. (2007). Addressing the STEM Challenge by Expanding Specialty Math and Science High Schools. Information Technology and Innovation Foundation. Retrieved from http://eric.ed.gov/?id=ED506571

Bancino, R., \& Zevalkink, C. (2007). Soft Skills: The New Curriculum for Hard-Core Technical Professionals. Techniques: Connecting Education and Careers, 82(5), 20-22.

Berland, L. K. (2013). Designing for STEM Integration. Journal of Pre-College Engineering Education Research, 3(1), $22-31$.

Capraro, R. M., \& Slough, S.W. (Eds.). (2008). Project-based learning: An integrated science, technology, engineering, and mathematics (STEM) approach. Rotterdam, the Netherlands: Sense.

Carnevale, A. P., Smith, N., \& Strohl, J. (2010). Help Wanted: Projections of Jobs and Education Requirements through 2018. Georgetown University Center on Education and the Workforce. Retrieved from http://eric.ed.gov/?id=ED524310

Committee on Prospering in the Global Economy of, \& the 21 st Century. (2007). Rising Above the Gathering Storm: Energizing and Employing America for a Brighter Economic Future. Washington, D.C.: National Academies Press. Retrieved from http://www.nap.edu/catalog/11463

Dewey, J. (1997). Experience And Education (Reprint edition). New York: Free Press.

Diaz-Rubio, I. (2013). Business Partnerships to Advance STEM Education: A Model of Success for the Nation. Committee for Economic Development. Retrieved from http://eric.ed.gov/?id=ED544373

Dixon, R. A., \& Brown, R. A. (2012). Transfer of Learning: Connecting Concepts during Problem Solving. Journal of Technology Education, 24(1), 2-17.

Doolen, T. L., \& Biddlecombe, E. (2014). The Impact of a Cohort Model Learning Community on First-Year Engineering Student Success. American Journal of Engineering Education, 5(1), 27-40.

Dubin, J. (2014). Keeping It Real: A Toledo Public School Prepares Students for College and Career. American Educator, 38(3), $18-23$.

Duran, M., Höft, M., Lawson, D. B., Medjahed, B., \& Orady, E. A. (2013). Urban High School Students’ IT/STEM Learning: Findings from a Collaborative Inquiry- and Design-Based Afterschool Program. Journal of Science Education and Technology, 23(1), 116-137. http://doi.org/10.1007/s10956-013-9457-5

Erdogan, N., \& Stuessy, C. L. (2015). Modeling Successful STEM High Schools in the United States: An Ecology Framework. International Journal of Education in Mathematics, Science and Technology, 3(1), 77-92. 
Harris, K. S., \& Rogers, G. E. (2008). Soft Skills in the Technology Education Classroom: What Do Students Need? Technology Teacher, 68(3), 19-24.

Havice, W. (2009). The power and promise of a STEM education: Thriving in a complex technological world. In International Technology and Engineering Educators Association (Ed.), The Overlooked STEM Imperatives: Technology and Engineering (pp. 10-17), Reston, YA: ITEEA.

Hoachlander, G., \& Yanofsky, D. (2011). Making STEM Real. Educational Leadership, 68(6), 60-65.

Holton, D., \& Clarke, D. (2006). Scaffolding and Metacognition. International Journal of Mathematical Education in Science \& Technology, 37(2), 127-143.

Hoover High School. (2016). Specialized Academics at Hoover High School. Retrieved March 25, 2016, from http://hooverhigh.al.hch.schoolinsites.com/?PageName=bc\&n=104084

Hougham, R. J., Eitel, K. C. B., \& Miller, B. G. (2015). Technology-Enriched STEM Investigations of Place: Using Technology to Extend the Senses and Build Connections to and Between Places in Science Education. Journal of Geoscience Education, 63(2), 90-97. http://doi.org/10.5408/12-399.1

Householder, D. L., \& Hailey, C. E. (2012). Incorporating Engineering Design Challenges into STEM Courses. National Center for Engineering and Technology Education. Retrieved from http://eric.ed.gov/?id=ED537386

Katehi, L., Pearson, G., \& Feder, M. (2009). Engineering in K-12 Education: Understanding the Status and Improving the Prospects. National Academies Press.

Kaye, K., Turner, J. F., \& Emigh, J. (2011). The CSI Academy: Encouraging Diverse Students to Consider Science Careers and Science Teaching. AILACTE Journal, 8, 66-82.

Mallard Creek High School. (n.d.). Building Tomorrow. Today. Retrieved March 25, 2016, from http://mchsaoe.weebly.com/about.html

Marshall, S. P. (2010). Re-Imagining Specialized STEM Academies: Igniting and Nurturing "Decidedly Different Minds", by Design. Roeper Review, 32(1), 48-60.

Mayor's Youth Employment Program. (2015). About MYEP. Retrieved March 25, 2016, from http://charmeck.org/city/charlotte/mayor/myep/Pages/AboutMYEP.aspx

Morrison, J., Roth McDuffie, A., \& French, B. (2015). Identifying Key Components of Teaching and Learning in a STEM School. School Science and Mathematics, 115(5), 244-255. http://doi.org/10.1111/ssm.12126

National Governors Association (NGA). (2007). Innovation America: Building a science, technology, engineering, and math [STEM] agenda. Retrieved from http://www.nga.org/files/live/sites/NGA/files/pdf/0702INNOVATIONSTEM.PDF

National Science Board. (n.d.). Science and Engineering Indicators 2012 - US National Science Foundation (NSF). Retrieved April 1, 2016, from http://www.nsf.gov/statistics/seind12/

NGSS Lead States. (2013). Next Generation Science Standards: For States, By States. Washington, DC:The National Academies Press.

Oleson, A. K., Hora, M. T., \& Benbow, R. J. (2014). STEM: How a Poorly Defined Acronym Is Shaping Education and Workforce Development Policy in the United States. WCER Working Paper No. 2014-2. Wisconsin Center for Education Research. Retrieved from http://eric.ed.gov/?id=ED556481

Peters Burton, E., Kaminsky, S. E., Lynch, S., Behrend, T., Han, E., Ross, K., \& House, A. (2014). Wayne School of Engineering: Case Study of a Rural Inclusive STEM-Focused High School. School Science and Mathematics, 114(6), 280290.

Pintrich, P. R., \& De Groot, E. V. (1990). Motivational and Self-Regulated Learning Components of Classroom Academic Performance. Journal of Educational Psychology, 82(1), 33-40.

President's Council of Advisors on Science and Technology (2012). Report to the President. Engage to excel: Producing one million additional college graduates with degrees in science, technology, engineering and mathematics. Washington, D.C.: Executive Office of the President.

Project Lead the Way. (2013, October 1). PLTW Engineering - Curriculum [Text]. Retrieved March 29, 2016, from https://www.pltw.org/our-programs/pltw-engineering/pltw-engineering-curriculum

Ricks, K. G., Richardson, J. A., Stern, H. P., Taylor, R. P., \& Taylor, R. A. (2014). An Engineering Learning Community to Promote Retention and Graduation of At-Risk Engineering Students. American Journal of Engineering Education, 5(2), 73-90.

Roberts, T. G. (2003). An Interpretation of Dewey's Experiential Learning Theory. Retrieved from http://eric.ed.gov/?id=ED481922

Roehrig, G. H., Moore, T. J., Wang, H.-H., \& Park, M. S. (2012). Is Adding the E Enough? Investigating the Impact of K-12 Engineering Standards on the Implementation of STEM Integration. School Science and Mathematics, 112(1), 31-44.

Roschelle, J. \& Teasley, S. (1995). The construction of shared knowledge in collaborative problem solving. In O'Malley, C. E., (ed.), Computer supported collaborative learning, (pp. 69-97). Heidelberg: Springer-Verlag.

Schachter, R. (2012). Not Your Grandparents' Vocational School. District Administration, 48(9), 66-68.

Slater, S. J., \& Slater, T. F. (2015). Questioning the Fidelity of the Next Generation Science Standards for Astronomy and Space Sciences Education. Journal of Astronomy \& Earth Sciences Education, 2(1), 51-64. 
Slough, S. W., \& Milam, J. O. (2013). Theoretical Framework for the Design of STEM Project-Based Learning. In R. M. Capraro, M. M. Capraro, \& J. R. Morgan (Eds.), STEM Project-Based Learning (pp. 15-27). Sense Publishers. Retrieved from http://link.springer.com/chapter/10.1007/978-94-6209-143-6_3

Southern Regional Education Board. (2012). Focusing on Challenging Content and Practical Applications in Science, Technology, Engineering and Mathematics (STEM) Studies in Middle Grades Schools, High Schools and Technology Centers. High Schools That Work. Southern Regional Education Board (SREB).

Stearns, L. M., Morgan, J., Capraro, M. M., \& Capraro, R. M. (2012). A Teacher Observation Instrument for PBL Classroom Instruction. Journal of STEM Education: Innovations \& Research, 13(3), 7-16.

STEM Academy of Hollywood. (2016). Mission and Vision / Overview. Retrieved March 26, 2016, from http://www.stemweb.org/domain/28

Stevenson, H. J. (2014). Myths and Motives behind STEM (Science, Technology, Engineering, and Mathematics) Education and the STEM-Worker Shortage Narrartive. Issues in Teacher Education, 23(1), 133-146.

Thomas, J., \& Williams, C. (2010). The History of Specialized STEM Schools and the Formation and Role of the NCSSSMST. Roeper Review, 32(1), 17-24.

Vance Academy of Engineering. (2016). About VAOE. Retrieved July 9, 2016, from http://vanceaoe.weebly.com/about-us.html

Vygotsky, L.S., 1978, Mind in Society: The Development of Higher Psychological Processes (Cambridge, MA: Harvard University Press).

White House Office of the Press Secretary (2013, Feb 12). Remarks by the president in the state of the union address. Washington, D.C. Retrieved from http://www.whitehouse.gov/thepress- office/2013/02/12/remarks-president-state-unionaddress

Wood, D., Bruner, J. S., \& Ross, G. (1976). The Role of Tutoring in Problem Solving. Journal of Child Psychology and Psychiatry, 17(2), 89-100. http://doi.org/10.1111/j.1469-7610.1976.tb00381.x 